\title{
Biofuels as liquid or gas for engines
}

\begin{abstract}
There is pressure to reduce the use of fossil fuels and to increase the use biofuels. Plant biomass is an excellent fuel and returns no more carbon dioxide to the atmosphere when it is burning than it has adsorbed while growing. This compilation of possible fuels with biological origin list a number of products around the world that can be of interest but concludes that $\mathrm{HVO}$ is the new product that can be of major interest for many manufacturers.
\end{abstract}

Keywords: biofuels, heat, electricity, cooling, motor fuels, plant biomass, solar energy, forests, agricultural land
Volume I Issue $3-2017$

Wästerlund I
Olasgarden Forest \& Roads, Solvägen, Sweden

Correspondence: Iwan Wästerlund, Olasgarden Forest \& Roads, Solvägen 9,918 32 Sävar, Sweden, Email iwanolasgarden@telia.com

Received: November 22, 2017 | Published: December 27, 2017

\section{Introduction}

Fuels of various kinds are used for the production of heat, electricity, cooling and motor fuels. Both in Sweden and internationally, there is pressure to reduce the use of fossil fuels and to increase the use of biofuels. Research is concentrated on fuels from forests and agricultural land. A greater quantity of biomass needs to be produced in an ecologically and economically sustainable manner. Costs need to be reduced in all parts of the various system chains, from fuel production to delivered heat, electricity or motor fuel. Efficiency needs to be improved and resources used more efficiently. Use of bioenergy is increasing worldwide.

Forests and agricultural land are gigantic solar collectors as a result of the ability of green plants to capture and store solar energy. Plant biomass is an excellent fuel, and returns no more carbon dioxide to the atmosphere when it is burnt than it has absorbed while growing. ${ }^{1}$

Demand is increasing for a number of reasons, such as many countries wanting to reduce their dependence on oil and reduce their carbon dioxide emissions. Various policy measures are being used which, together with the high price of oil, encourage industry and consumers to use more biofuels. The use of biofuels in Sweden has doubled since the 1970s, with substantial research program having contributed to this development. Sweden now has access to fuels and technologies that are available, both efficient and environmentally benign, but there are still substantial needs.

The supply of biofuels can be doubled increasing the use of biofuels necessitates supply from sustainable sources. On the basis of various investigations and assumptions, it should be possible to increase the supply of biofuels in Sweden from 112TWh in 2005 to about 130 TWh by Anon et al. ${ }^{2}$ By 2050, it should be possible to double the supply, to about 230TWh. More efficient forestry should make it possible to increase the production of forest fuels, both from primary production as well as in the form of by-products from the forest industry, while agriculture can deliver crops such as Salix, hybrid aspen, grains, oilseeds, energy grass such as reed canary grass, and various by-products from the foodstuffs chain. Some scenarios assume a significant increase in production from arable land.

Fuels of various kinds are used for the production of heat, electricity, cooling and motor fuels. Both in Sweden and internationally research is concentrated on fuels from forests and agricultural land. ${ }^{2}$ A greater quantity of biomass needs to be produced in an ecologically and economically sustainable manner. Plant biomass is an excellent fuel, and returns no more carbon dioxide to the atmosphere when it is burnt than it has absorbed while growing. ${ }^{1}$

Oil, coal and natural gas supply $87 \%$ of the world's energy needs, in comparison with which the use of biofuels is low. ${ }^{2}$ However, demand is increasing for a number of reasons, such as many countries wanting to reduce their dependence on oil and reduce their carbon dioxide emissions. Various policy measures are being used which, together with the high price of oil, encourage industry and consumers to use more biofuels. The EU has set targets for the use of renewable energy, with bioenergy playing a major part. Farmers are now also better paid for the production of biofuels.

The use of biofuels in Sweden has doubled since the 1970s, with substantial research program having contributed to this development. Sweden now has access to fuels and technologies that are available, efficient and environmentally benign, but there are still substantial needs.

\section{Biomaterial to use for fuels}

Logging residues can partially be converted to liquid fuel. Petrol engines can use ethanol and methanol. Ethanol use the holocellulose part of wood and mainly after cracking out the sugar part which after fermentation become alcohol, which is a difficult part, since the at most $25 \%$ of the wood part is used and the energy density part is only $85 \%$ of the present ordinary petrol when used in cars.

\section{Black liqour}

Approximately 7 tonnes of black liquor are produced in the manufacture of one tonnes of pulp. The black liquor is an aqueous solution of lignin residues, hemicellulose, and the inorganic chemicals. Normally the in organics I black liquor are $40-45 \%$ soaps, $35-45 \%$ lignin and $10-15 \%$ other organics. The extractives give tall oil soap and crude turpentine. ${ }^{3}$

Pulp mills have used black liquor as an energy source since at least the 1930s. Most kraft pulp mills use recovery boilers to recover and burn much of the black liquor they produce, generating steam and recovering the cooking chemicals (sodium hydroxide and sodium sulphide used to separate lignin from the cellulose fibres needed for papermaking). This has helped paper mills reduce problems with water emissions, reduce their use of chemicals by recovery and reuse, and become nearly energy self-sufficient by producing, on average, 66percent of their own electricity needs on-site. 
In the United States, paper companies have consumed nearly all of the black liquor they produce since the 1990s. As a result, the forest products industry has become one of the United States' leading generators of carbon-neutral renewable energy, producing approximately 28.5 terawatt hours of electricity annually. ${ }^{4}$

\section{DME (Di metyl ether)}

It is also a promising fuel in diesel engines, petrol engines (30\% DME / 70\% LPG), and gas turbines. For diesel engines, an advantage is the high cetane number of 55, compared to that of diesel fuel from petroleum, which is $40-53$. Only moderate modifications are needed to convert a diesel engine to burn dimethyl ether. The simplicity of this short carbon chain compound leads during combustion to very low emissions of particulate matter, $\mathrm{NO}_{x}$, and $\mathrm{CO}$. For these reasons as well as being sulfur-free, dimethyl ether meets even the most stringent emission regulations in Europe (EURO5), U.S. (U.S. 2010), and Japan (2009 Japan).

Dimethyl ether (DME) is being developed as a synthetic second generation biofuel (BioDME), which can be manufactured from lignocellulosic biomass. Currently the EU is considering BioDME in its potential biofuel mix in 2030; the Volvo Group is the coordinator for the European Community Seventh Framework Programme project BioDME where Chemrec's BioDME pilot plant based on black liquor gasification is nearing completion in Piteå, Sweden. ${ }^{3}$

\section{Methanol}

A factory for making methanol is a quite expensive fabric to build but when running it can give a rather cheap product. The major disadvantages are that methanol is aggressive to all rubber sealings which have to be changed. Other disadvantage is that it is toxic for humans.

However, methanol is low in energy content of $19.7 \mathrm{MJ} / \mathrm{kg}$ the extra water produced also makes the charge rather wet and with the formation of acidic products during combustion, the wearing of valves, valve seats and cylinder might be higher than with hydrocarbon burning. Certain additives may be added to the fuel in order to neutralize these acids. ${ }^{4}$

\section{Ethanol}

Ethanol is produced after cracking the cellulose component in wood into glucose which can be fermented like many other carbohydrates rich products like maize or sugar beets and sugar cane. Often used as blends into gasoline, which is a difficult part, since the at most $25 \%$ of the wood part is used and the energy part of the fuel is only $85 \%$ of the ordinary petrol when used in the car.

\section{REM}

REM (Rape Methyl Ester) was during a period quite popular to mix into other fuels but there are three major disadvantages. One being it becomes stiff during cold climate (-degrees $\mathrm{C}$ ) and contractors coming to an ice-cold cabin wintertime were furious because the diesel heater had stopped due to an ice plug in the fuel pipes. Second drawback was that EU dictated (2020, no subsidies to agricultural grown fuel) that agricultural land should not be used for fuel production. The third drawback is that in the zone between water and REM (water can easily occur as condensate in tanks and barrels) and in this zone microorganism may grow and cause a black clogg which stop the flow in filters. ${ }^{5}$

\section{Fame}

FAME (Fatty Acid Methyl Ester) is a type of fatty acid ester that is derived by transesterification of fats with methanol. The base is REM. The molecules in biodiesel are primarily FAMEs, usually obtained from vegetable oils by transesterification. They are used to produce detergents and biodiesel. FAMEs are typically produced by an alkali-catalyzed reaction between fats and methanol in the presence of base such as sodium hydroxide or sodium methoxide. The same thing said about REM is also valid for FAME (Table 1). Most of the biofuels are used as blends by adding $3-10 \%$ into fossil fuels to reduce the consumption of fossil fuels. For diesel engines we have REM and above all HVO introduced by the Finnish Neste Oil (HVO: Hydrogenerated vegetated oils). More later on about HVO.

Table I Energy density for some fuels (mainly from ${ }^{4}$ and SPBI2017)

\begin{tabular}{|c|c|c|c|c|}
\hline Fuel & MJ/kg & MWh/Litre & Density & Use \\
\hline Diesel & 41.5 & I 1.528 & & Diesel, motor \\
\hline Gasoline & 46.4 & & & Otto motor \\
\hline Black liquor & 11.7 & 3.25 & & Diesel, motor \\
\hline Wood tar & & & 1.05 & Diesel, motor \\
\hline Wood pellets & 17.3 & 4.8 & & $\begin{array}{l}\text { Heating, } \\
\text { electricity }\end{array}$ \\
\hline Peat, $\mathrm{m}^{3}$ & 3.24 & & & $\begin{array}{l}\text { Heating, } \\
\text { electricity }\end{array}$ \\
\hline Ethanol & 26.4 & & & Otto motor \\
\hline $\begin{array}{l}\text { Methanol } \\
(M I 00)\end{array}$ & $\begin{array}{l}19.7- \\
22\end{array}$ & & 0.79 & Otto motor \\
\hline RME $\mathrm{Nm}^{3}$ & & 9.15 & & Diesel, motor \\
\hline $\begin{array}{l}\text { Hydrogen, } \\
\text { compres. }\end{array}$ & 26.4 & & & Otto motor \\
\hline $\operatorname{DME}\left(\mathrm{C}_{2} \mathrm{H}_{5} \mathrm{O}\right)$ & 28.8 & & $2,1146 \mathrm{~kg} / \mathrm{m}^{3}$ & Diesel ,motor \\
\hline $\mathrm{FAME} / \mathrm{m}^{3}$ & 9.15 & & & Diesel. motor \\
\hline Biogas $/ \mathrm{Nm}^{3}$ & 9.7 & & & $\begin{array}{l}\text { Otto motor, } \\
\text { heating }\end{array}$ \\
\hline $\mathrm{HVO} / \mathrm{m}^{3}$ & 9.44 & & $0.77-0.79$ & Diesel, motor \\
\hline
\end{tabular}

\section{Wood-tar creosote}

Wood-tar creosote is a colourless to yellowish greasy liquid with a smoky odor, produces a sooty flame when burned, and has a burned taste. It is non-buoyant in water, with a specific gravity of 1.037 to 1.087 , retains fluidity at a very low temperature, and boils at 205$225^{\circ} \mathrm{C}$. When transparent, it is in its purest form. Dissolution in water requires up to 200 times the amount of water as the base creosote. The creosote is a combination of natural phenols: primarily guaiacol and creosol (4-methylguaiacol), which will typically constitute $50 \%$ of the oil; second in prevalence, cresol and xylenol; the rest being a combination of monophenols and polyphenols (Figure 1).

When wood is heated above $270^{\circ} \mathrm{C}$ it begins a process of decomposition called carbonization. If air is absent the final product, since there is no oxygen present to react with the wood, is charcoal. If air, which contains oxygen, is present, the wood will catch fire and burn when it reaches a temperature of about $400-500^{\circ} \mathrm{C}$ and the fuel 
product is wood ash. If wood is heated away from air, first the moisture is driven off and until this is completed, the wood temperature remains at about $100-110^{\circ} \mathrm{C}$. When the wood is dry its temperature rises and at about $270^{\circ} \mathrm{C}$ it begins to spontaneously decompose and, at the same time, heat is evolved from. ${ }^{4}$

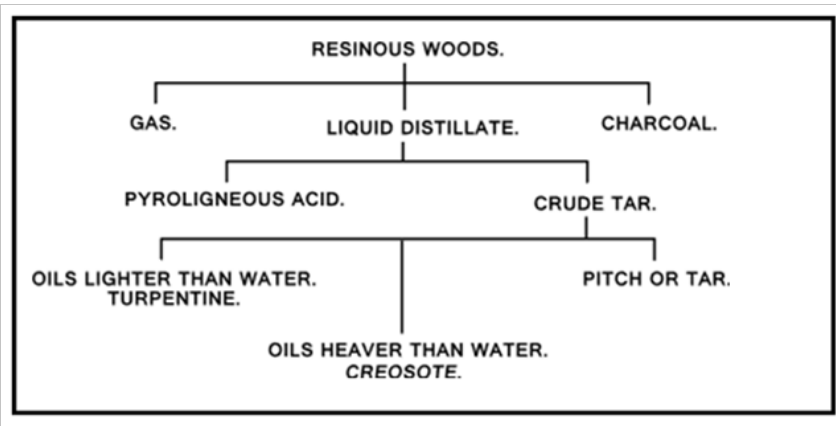

Figure I Wood pyrolysis processes chemicals.

Modern pyrolysis processes, which is the direct thermal decomposition of biomass in the absence of oxygen, which prevents combustion, to obtain an array of solid (biochar), liquid-Pyrolysis oil (bio-oil/pyrolysis-oil), and gas (syngas) products (Figure 1). The specific yield from the pyrolysis is dependent on process conditions, such as temperature, and can be optimized to produce either energy or biochar, occurs more quickly at the higher temperatures, typically requiring seconds instead of hours. High temperature pyrolysis is also known as gasification, and produces primarily syngas.

\section{Biogas}

Biogas typically refers to a mixture of different gases produced by the breakdown of organic matter in the absence of oxygen (Table 2). Biogas can be produced from raw materials such as agricultural waste, manure, municipal waste, plant material, sewage, green waste or food waste. Biogas is a renewable energy source.

Table 2 Composition of biogas ${ }^{4}$

\begin{tabular}{lll}
\hline \multicolumn{3}{l}{ Typical composition of biogas } \\
\hline Compound & Formula & $\%$ \\
\hline Methane & $\mathrm{CH}_{4}$ & $50-75$ \\
Carbon dioxide & $\mathrm{CO}_{2}$ & $25-50$ \\
Nitrogen & $\mathrm{N}_{2}$ & $0-10$ \\
Hydrogen & $\mathrm{H}_{2}$ & $0-1$ \\
Hydrogen sulphide & $\mathrm{H}_{2} \mathrm{~S}$ & $0-3$ \\
Oxygen & $\mathrm{O}_{2}$ & $0-0.5$ \\
\hline
\end{tabular}

Biogas is primarily methane $(\mathrm{CH})$ and carbon dioxide $\left(\mathrm{CO}_{2}\right)$ and may have small amounts of hydrogen sulfide $\left(\mathrm{H}_{2} \mathrm{~S}\right)$, moisture and siloxanes. The gases methane, hydrogen, and carbon monoxide (CO) can be combusted or oxidized with oxygen.

Biogas can be compressed, the same way natural gas is compressed to $\mathrm{CNG}$, and used to power motor vehicles. In the UK, for example, biogas is estimated to have the potential to replace around $17 \%$ of vehicle fuel. It qualifies for renewable energy subsidies in some parts of the world. Biogas can be cleaned and upgraded to natural gas standards, when it becomes bio-methane. Biogas is considered to be a renewable resource because its production-and-use cycle is continuous, and it generates no net carbon dioxide.

\section{HVO}

HVO (Hydrogenerated Vegetated Oils) is by $80 \%$ of the world market produced by the Finnish company Neste Oil who also have factories in Rotterdam and Singapore. The main raw material is based mainly on butchery waste but palm oil is occurring also but not considered as ecological correct, instead black liqour could be used. In the first step all salts, particles and water are removed. Secondly the raw material is subjected to extreme pressures and high temperatures. Then, carbohydrates that can be linked to longer molecule chains are removed. Formed hydrogen hydrogen sulphide $\left(\mathrm{H}_{2} \mathrm{~S}\right)$ are removed then. Now we have a product that completely can replace diesel oil and a number of lorry manufacturers (Scania, Volvo and Mercedes) accept it as engine fuel.

Replacement of fossil diesel with HVO 100 diesel can even result in less fuel consumption in the engine. Today (2017) to increase the supply of raw material research is turned towards logging residuals. ${ }^{4}$

Hydrogenation-to treat with hydrogen-is a chemical reaction between molecular hydrogen $\left(\mathrm{H}_{2}\right)$ and another compound or element, usually in the presence of a catalyst such as nickel, palladium or platinum.

\section{Electricity}

Electricity is launched this year for many different vehicles ${ }^{6}$ and they could be an interesting alternative if the electricity is made in a green way e.g. with hydropower. Elon Musk launched recently his Tesla Semi lorry running on battery. To be produced in 2019 and claimed to running $800 \mathrm{~km}$ after full charging.

\section{Conclusion}

There are many products made that are biologically usable in different applications but so far it seems to be HVO 100 and black liqour that are the best product fitting in many applications, also being ecologically correct by being made from residuals but palm oil is not accepted as green oil for production of HVO. Electricity is a possible source but to the vehicles it must be made in an ecological way and can be of interest only for some countries rich in e.g. hydropower.

\section{Acknowledgements}

None.

\section{Conflict of interest}

The author declares that there is no conflict of interest.

\section{References}

1. Nordin A. With Future forest into the future. A magasin from Future Forest and SLU, 2017. 15 p.

2. Anon. Swedish Energy Agency. Stockholm and Eskilstuna, Sweden; 2014.

3. Anon. Articles publiced in the newspaper ATL, LRF Media. Stockholm, Sweden; 2017.

4. Anon. Wikipedia.org/wiki.2017. 2017.

5. Wästerlund I. Listening to oral presentations from Swedish forest companies at Swedish Forest Research Institute. Sweden; 2009.

6. IVT. International Vehicle Industrial Technology, off road. Sweden; 2018. 